\title{
The Phrygian god Bas
}

\section{Bartomeu Obrador-Cursach, University of Barcelona *}

Among the gods identified in the Phrygian corpus, Bas stands out because of the lack of a Greek counterpart.

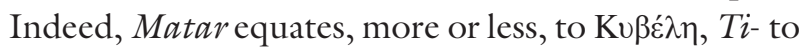

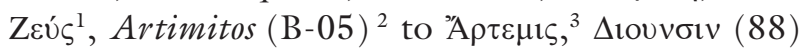
to $\Delta$ tóvvбos, and Mas (48) to Mív. ${ }^{4}$ Yet Bas remains without a clear equivalent and seems to only appear in Phrygian texts. He occurs almost eight times in different contexts of both the Old Phrygian (OPhr.) and New Phrygian (NPhr.) corpora. This makes Bas

\footnotetext{
* This paper was funded by the research project Los dialectos lúvicos del grupo anatolio en su contexto lingüístico, geográfico e histórico (Ref. FFI2015-68467-C2-1-P) granted by the Spanish Ministry of Economy, Industry, and Competitiveness.

${ }^{1}$ A. Lubotsky, "The Phrygian Zeus and the problem of the 'Lautverschiebung," Historische Sprachforschung 117 (2004): 230-31.

${ }^{2}$ The enumeration and readings of the Old Phrygian inscriptions (transcribed in the Latin alphabet) are given according to C. Brixhe and M. Lejeune, Corpus des Inscriptions Paléo-Phrygiennes I. Texte (Paris, 1984) (abbreviated here as CIPPh) and its supplements. The enumeration and readings of New Phrygian inscriptions (in the Greek alphabet) are given according to the traditional enumeration developed from the works of W. M. Ramsay. In the case of recent findings, I use the system established by $\mathrm{O}$. Ligorio and A. Lubotsky, “Фригийский язык, in Языки мира, Реликтовые индоевропейские языки Передней и Центральной Азии, ed. Ю. Б. Коряков and А. А. Кибрик (Moscow, 2013), 182.

${ }^{3}$ C. Brixhe, "Corpus des Inscriptions Paléo-phrygiennes. Supplément II,” Kadmos 43 (2004): 55-56.

${ }^{4}$ A. Lubotsky, "New Phrygian Inscription No. 48, Palaeographic and Linguistic Comments," in Frigi e Frigio. Atti del $1^{o}$ Simposio Internazionale. Roma, 16-17 ottobre 1995, ed. R. Gusmani, M. Salvini, and P. Vannicelli (Roma, 1997), 122 n. 10.
}

the third most referenced god after Ti- (the Phrygian Zeus, documented almost exclusively in NPhr. curses) and Matar (the Mother-Goddess, exclusively in OPhr. monuments). The high number of references allow for the analysis of his purpose and the identification of the origin of his name in the light of our increasing knowledge of Phrygian and the general Anatolian framework.

The oldest occurrence of this theonym is documented in the Luwian city of Tuwanuwa in Cappadocia (called Túava in Greek, and currently called Kemerhisar). The name of Bas can be read on a fragment of a severely damaged stele discovered in 1908 (T-02b). Although most of the monument is lost, its shape is believed to be parallelepiped with a semicircular summit, similar to the Neo-Assyrian style. ${ }^{5}$ C. Brixhe interpreted the significance of this document as a signal of Phrygian suzerainty of this country in the late eighth century BC. ${ }^{6}$ In that case, the historical

\footnotetext{
${ }^{5} \mathrm{CIPPh}, 253-68$. Another very similar stele was found in modern times also in Tyana (T-03): see A. Çınaroğlu and E. Varinlioğlu "Eine neue altphrygische Inschrift aus Tyana," Epigraphica Anatolica 5 (1985): 5-11. Phrygian contacts with Tyana are also evident in the Ivriz relief, where the king Warpalawas (known to be ally of Midas) is depicted wearing Phrygian ornaments (his belt, fibula and, very likely, his tunic). See C. Brian Rose, "Fieldwork at Phrygian Gordion, 2013-2015," American Journal of Archaeology 121 (2017): 159.

${ }^{6} \mathrm{C}$. Brixhe, "Les inscriptions paléo-phrygiennes de Tyane: leur intérêt linguistique et historique," in La Cappadoce Méridionale
} 
background of the Phrygian presence in such a place must be Midas' campaigns for hegemony over the Syro-Hittite states, and against Sargon II as recorded by Assyrian sources. ${ }^{7}$ Despite the opaqueness of this fragmented text, $\mathrm{T}-02 \mathrm{~b}$ contains the highest number of words readable in all fragments from Tyana, and is the only known preserved and datable text contemporaneous to King Midas in which he is mentioned (1. 3). The fragment reads as follows:

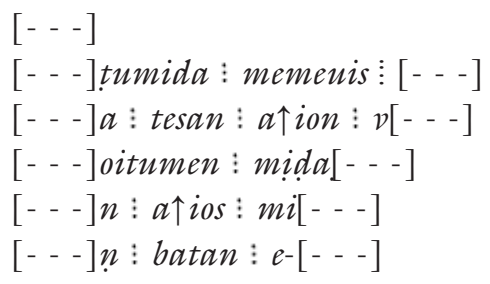

Unfortunately, little can be said about this inscription. The sequence tesan was dubiously identified as borrowed from the Lydian taśse-, "stele," agreeing with the adjective $a \uparrow$ ion in sg.acc. However, this Lydian word must be read as taierv, ${ }^{9}$ and Phrygian tesan can be considered a pronominal cluster similar to esa $i=t\left(\mathrm{~W}-0 \mathrm{lb}\right.$, sg.dat.),${ }^{10}$ and analyzed as $t=e s a n$ (sg.acc.), if not an $a$-stem noun. In addition, perhaps [- - ]-tumida is a personal name in sg. acc. followed by the term memenis, attested as memevais in $\mathrm{M}-0 \mathrm{lb}$ and M-02 (in both inscriptions, a possible patronymic). In any event, these interpretations are precarious because of the lack of parallels, and because the sole verifiable information of $\mathrm{T}-02 \mathrm{~b}$ is the reference of Bas appearing for the first time in a Luwian country.

This god perhaps appears in two other OPhr. inscriptions. The first one, the inscription B-04 (from Bithynia, fifth or fourth century BC), seems to contain

jusqu'à la fin de l'époque romaine. État des recherches. Actes du Colloque d'Istanbul (Institut Français d'Études Anatoliennes) 13-14 avril 1987, ed. Le Guen-Pollet and O. Pelon (Paris, 1991), 45-46.

7 These campaigns are recorded in Assyrian texts from Sargon II's reign (722-705 BC), where the Phrygian king is called ${ }^{\mathrm{I}}$ Mitā à sàr $m \bar{a} t$ Muškin, "Mitā, king of the land of the Muški." In these texts, he is accused of being behind conspiracies of two tributary states of the Assyrians (in 718 BC with Kiakki of Šinuhtu, and in 717 BC with Pisiri of Karkamiš), and he is further said to have conquered the cities of Harrua and Ušanis, and influenced Tabal. These hostilities continued until almost $709 \mathrm{BC}$, when he is said to have sent presents as a tribute to Sargon II on his own initiative.

${ }^{8}$ See V. Orel, The Language of Phrygians. Description and Analysis (Delmar, NY, 1997), 310 and 461.

${ }^{9} \mathrm{D}$. Schürr, "Zu lykisch $\vartheta \vartheta \tilde{e}$ und seiner etymologischen Interpretation," Indogermanische Forschungen 121 (2016): 123-30.

${ }^{10}$ See Ligorio and Lubotsky, “Фригийский язык, 184. the accusative of this theonym, but the text is hard to read and its context is unclear. ${ }^{11}$ The other inscription from a little bit later (fourth century $\mathrm{BC}$ ), the graffito G-221 incised on a sherd from Gordion, could be adduced here, but the pertinent sequence is read as bata $m$ by CIPPh, ${ }^{12}$ and the meaning of the whole text remains unclear.

The other seven occurrences of the theonym Bas are recorded in the NPhr. sub-corpus, from the second and third century AD. He is featured six times as the agent of three different curses against tomb desecrators, always mentioned in their apodoses..$^{13}$ Note that curses are by far the most common kind of text in the NPhr. corpus, since only 13 of the 117 known inscriptions contain anything more than a curse. ${ }^{14}$ Two inscriptions contain the first imprecative formula mentioning Bas, 33 and 36, both found in Sinanlı:

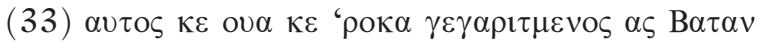
$\tau \varepsilon v \tau$ Tous

(36) $\alpha v \tau \circ \zeta \kappa^{\prime}$ ov $\mid \alpha \kappa^{\prime}$ орок $\alpha[\gamma] \varepsilon \gamma[\alpha \rho \tau] \mu \varepsilon[v] \mathrm{o} \mid \varsigma \alpha \mathrm{B} \alpha \tau \alpha \nu$ $\tau \mid \varepsilon v \tau$ тous

The meaning of this text roughly translates to: "and let him and his орока (offspring?) be at the mercy of Bas $\tau \varepsilon v \tau$ tous." Some of these words are com-

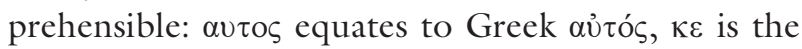
copulative conjunction (<PIE * $k^{u} e$, "and"), ov $\alpha$ is the 3sg.fem. possessive pronoun (< PIE * sue-), and $\gamma \varepsilon \gamma \alpha \rho \imath \tau \mu \varepsilon v o \varsigma$ is the masc.sg.midd.-pass.part. (parallel

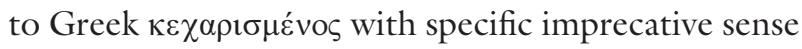
found in Anatolia). However, орока remains obscure as well as $\tau \varepsilon v \tau$ tous, which does not seem to have a good explanation. The latter has been equated to the discussed word *teutéh ${ }_{2}^{-}$, "people," attested only in the Italian, Celtic, German, and Baltic branches of Indo-

\footnotetext{
${ }^{11}$ Brixhe, "Corpus des Inscriptions Paléo-phrygiennes. Supplément II," 41.

${ }^{12} \mathrm{CIPPh}, 179$.

${ }^{13}$ A common curse can be divided into two different parts: protasis and apodosis. Protases indicate who the potential addressee of the curse is. A standard protasis in NPhr. says as follows: 105

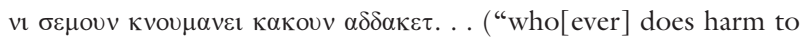
this tomb. .."). Apodoses mention the punishment considered to happen to the addressee of the curse, and very often name a god or group of gods as the agent(s) of that punishment (normally Tt-, only substituted by Bas as we will see, and once by Dionysos). A common NPhr. apodosis reads in this way: $\mu \varepsilon \delta \varepsilon \omega \varsigma \kappa \varepsilon \zeta \varepsilon \mu \varepsilon \lambda \omega \varsigma \kappa \varepsilon \alpha$

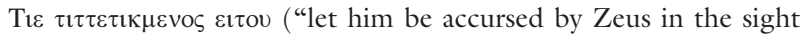
of gods and men").

14 These inscriptions, nos. 9, 15, 18, 30, 31, 48, 57, 69, 98, 116, 128 , and 130 , only represent $11 \%$ of the whole corpus.
} 
European languages. ${ }^{15}$ For this reason, this Phrygian word has been often considered a borrowing from Galatian. ${ }^{16}$ Since these two inscriptions, as indicated above, were found in Sinanlı in the most northeastern point where NPhr. texts are documented, on the border with Galatia, ${ }^{17}$ this explanation seems likely. However, in light of the few occurrences of this word in the poorly-attested language of the Galatians (see, e.g., the tribal names Ambitoutus, established near Gordion according to Plin. HN 5.146, and Toutobodiaci, associated to Tectosages according to Plin. HN $5.146)$, which shows that in this language *teut- became tout-, this suggested borrowing can easily be refuted. Consequently, a new interpretation must be given. Because it appears in a position where a verb in the imperative mood is expected (see, e.g., 88:

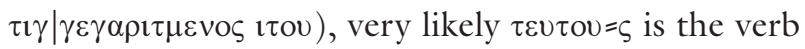
of this imprecative apodosis. ${ }^{18}$ Thus, the sequence - $\tau$ ov corresponds to the $3 \mathrm{sg}$.impv. ending, although its attached sigma and meaning remain unexplained. Either way, $\tau \varepsilon v \tau o v$ is the only word of this apodosis which can be interpreted as a verb.

The second imprecative apodosis with references to Bas is contained on two inscriptions, found in two cities near by one another in the north of the NPhr. epigraphic area, Güney and Erten respectively:

(86) $\mathrm{B} \alpha[\varsigma]$ | tot $\beta \varepsilon \kappa о \varsigma ~ \mu \varepsilon \beta \varepsilon \rho \varepsilon[\tau]$

(111) Bas tor $\beta \varepsilon \kappa o \varsigma ~ \mu \varepsilon \beta \varepsilon \rho \varepsilon \tau$

The components of this apodosis are relatively clear: the sg.nom. Bas is the subject, $10 \mathrm{t}$ is a pronoun in sg.dat., $\beta \varepsilon \kappa о \varsigma$ is the word for 'bread' (a neut.sg.acc.), $\mu \varepsilon$ is the prohibitive particle, ${ }^{19}$ and $\beta \varepsilon \rho \varepsilon \tau$ the verb

${ }^{15}$ R. S. P. Beekes, "The origin of Lat. aqua, and of *teuta $\bar{a}$ 'people'," The Journal of Indo-European Studies 26/3-4 (1998): 461-65.

${ }^{16}$ First proposed by W. M. Ramsay, "Neo-Phrygian Inscriptions," Jahreshefte des Österreichischen Archäologischen Institutes in Wien 8 (Beiblatt) (1905), 97, it was still considered by Ligorio and Lubotsky in “Фригийский язык," 194.

${ }^{17} \mathrm{~A}$ third occurrence of this word might be $\tau \varepsilon v \tau \omega \sigma \iota$ (NPhr. 116), found in an obscure sentence of a funerary stele not related to the imprecative part of the text.

${ }^{18}$ This possibility was suggested to me by an anonymous reviewer of this paper whom I would like to thank. However, I must add that a second anonymous reviewer was not convinced by this possibility because of the "enigmatic" $s$ attached to $\tau \varepsilon v \tau o v$.

${ }^{19}$ In the light of the Phrygian shift ${ }^{*} \bar{e} /{ }^{*} e h_{1}>\bar{a}$ and the preposition $\mu \varepsilon$ (in the formula $\mu \varepsilon \delta \varepsilon \omega \varsigma \kappa \varepsilon \zeta \varepsilon \mu \varepsilon \lambda \omega \varsigma \kappa \varepsilon$ ), the communis opinio considers $m e$ (B-05) / $\mu \varepsilon$ a preverb against O. Haas's previous identification of it as inherited from the PIE particle ${ }^{*} m_{1} h_{1}$ in 3sg.pres.subj. which goes back to PIE * $b^{b}$ er-, "to bear" (LIV $\left.{ }^{2} 76-77\right) .{ }^{20}$ Regarding the meaning of this apodosis, during the last Phrygian Conference (early November of 2015 in Eskişehir), A. E. Hämmig ${ }^{21}$ adduced suitable Greek parallels found in Anatolia and collected by J. H. M. Strubbe:22

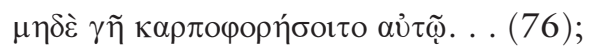

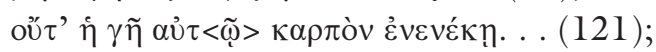

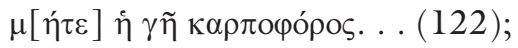

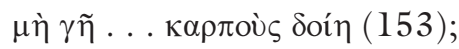

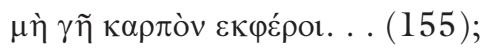

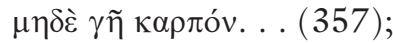

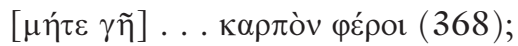

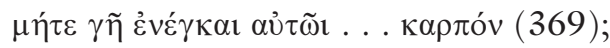

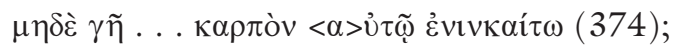

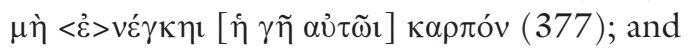

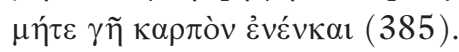

According to Hämmig, $\beta \varepsilon \kappa \cos _{\text {can }}$ be equated to

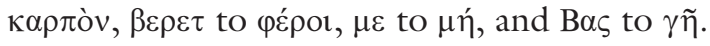

Although this interpretation is convincing, the equation $\mathrm{B} \alpha \varsigma \sim \gamma \tilde{\eta}$, first argued by Haas, ${ }^{23}$ is, as she admits, difficult to support from a linguistic point of view. The Greek word is not a $t$-stem noun, and the correspondence between Phrygian $\beta$ and Greek $\gamma$ is

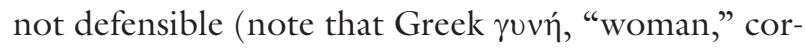
responds to Phrygian knays). Of course, this parallel is not necessarily phonetic, but only semantic regardless of the etymologies. However, these expressions look like a specific formula from Caria $(76,121$, and

(Die phrygischen Sprachdenkmaler [Sofia, 1966], 95). Nevertheless, during the last Phrygian Conference, Hämmig and I argued that before the verbs of the imprecative apodoses, $\mu \varepsilon$ makes more sense

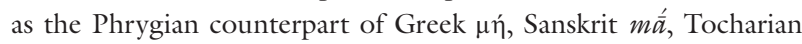
A and B $m \bar{a}$, etc. Even OPhr. mekos (B-07, the Phrygian stele from Daskyleion) can be analyzed as the combination of the prohibitive particle with the indefinite pronoun $k o s\left(<\mathrm{PIE} * k^{u} o s\right)$ with the meaning "no one, nobody" (I will return to this issue in my forthcoming PhD dissertation). It must be said, however, that the reason why the Phrygian shift $* \bar{e} /{ }^{*} e h_{1}>\bar{a}$ did not operate here (instead of * $m \bar{a})$ remains unclear.

${ }^{20}$ H. Rix, Lexikon der indogermanischen Verben (Wiesbaden, $2001^{2}$ ) (abbreviated here as LIV²).

${ }^{21}$ A. E. Hämmig, "The Language of the Phrygians and its Ongoing Decipherment," in G. R. Tsetskhladze, ed., The Phrygian Lands Over Time (Leuven, forthcoming).

${ }^{22}$ J. H. M. Strubbe, APAI EПITYMBIOI. Imprecations against Desecrators of the Grave in the Greek Epitaphs of Asia Minor. A Catalogue (Bonn, 1997); the numbers of these Greek inscriptions are given according to this catalogue.

${ }^{23}$ Haas, Die phrygischen Sprachdenkmaler, 95. 
$122)$ and, especially from Lycia $(357,368,369,374$, and 377 ) with only two occurrences in Pontus (153 and 155). Indeed, it is never attested in Phrygia. Moreover, the only $\gamma \tilde{\eta}$ featured in a Greek imprecation is Strubbe's no. 223, which shows a similar idea, but gets expressed in a different way: oṽ்o $\mu \eta \dot{~} \varepsilon \gamma \tilde{\eta} \varsigma$

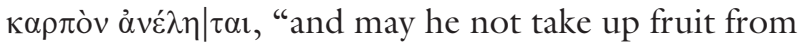
earth." Here the subject is not the earth, and this is an essential detail. In Phrygia, the earth never appears personified, and the provider of crops is Zeus, as will be seen below. Thus, Bas is somehow related to Zeus rather than to earth. Nevertheless, the Greek parallels adduced by Hämmig are useful to understand the Phrygian formula (leaving aside the question of "earth"), and B $\alpha \varsigma$ toเ $\beta \varepsilon \kappa o \varsigma \mu \varepsilon \beta \varepsilon \rho \varepsilon \tau$ can be translated as: "may Bas not produce food to him."

Following our analysis, another apodosis type from Erten shows Bas related to bread:

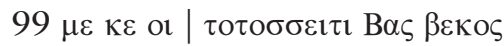

The words are more or less the same; they only differ in the presence of the copulative conjunction $\kappa \varepsilon$

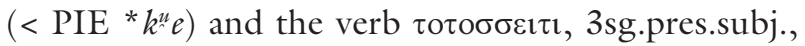
whose root has been recently identified by Hämmig as going back to ${ }^{*} d e h_{3}$, " give." ${ }^{25}$ Consequently, the meaning of this sentence is: "and may Bas not give him bread." Here, "bread" also refers to "food" via synechdoche.

In addition, if Hämmig's likely new reading of NPhr. 18 is accepted, then in this kind of apodosis, Bas is once substituted by the obscure word $\sigma \alpha \rho v a v$ :

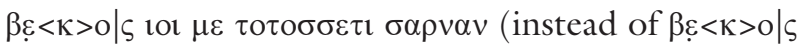

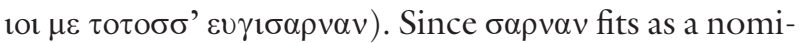
native singular (-ēn, see, e.g., iman, imenos), it could be considered an epiklesis of the same god. Recently,

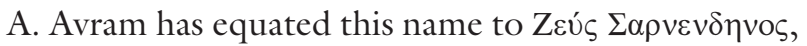
read in Greek inscriptions from northeast Phrygia / northwest Galatia (with one occurrence in Bithynia and Dacia). ${ }^{26}$ However, its meaning remains unclear.

\footnotetext{
${ }^{24}$ During the last Phrygian Conference, I analysed this formula in the light of Semitic and Hieroglyphic Luwian curses: the bilingual inscription from Tell Fekherye (Assyrian 28-29 and Aramaic 17-18) and KARKAMIš Al la $\$ 27$, respectively (B. Obrador-Cursach, "The Luwian origin of the Phrygian imprecations," forthcoming in Tsetskhladze, ed., Phrygian Lands Over Time). However, I operate with Hämmig's parallels because they are closer in time and place.

${ }^{25}$ She argued this very convincing identification during the last Phrygian Conference.

${ }^{26}$ A. Avram, "Two Phrygian gods between Phrygia and Dacia," Colloquium Anatolicum 15 (2016): 70-83. I would like to thank
}

The last imprecation featuring the god Bas is found on the inscription 128:

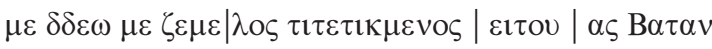
Opovevav $\kappa \varepsilon$.

As one of the most common formulae, the meaning of this passage is generally accepted, although it is the only occurrence of the kind in which there are two guarantees: "let him be accursed in the sight of gods and men by Bas and the Keeper(?)." Here the accusative is governed by the preposition as (< PIE ${ }^{*} h_{1} n s$ ), and replaces the more common as Tiav ("by Zeus"). ${ }^{27}$ Moreover, it is also coordinated with the sg.acc. opovevav, whose sg.nom. is opovav, attested in NPhr. 48. In this last text, a quasi-bilingual GreekPhrygian, this term has been equated to the Greek

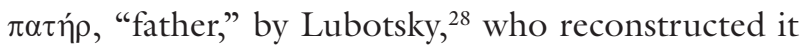
as *soruén, a form related to Greek oũpos "watcher, $\operatorname{guard}(\operatorname{ian}), "<{ }^{*}$ sor-uo. According to Lubotsky, it is an epithet of Phrygian Zeus. ${ }^{29}$ The formula $\mu \varepsilon \delta \varepsilon \omega \varsigma \kappa \varepsilon$

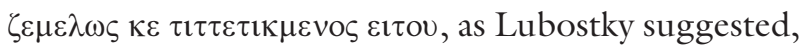
follows a Luwian apodosis attested in KARKAMIŠ A $2+3 \$ 24: w a / i$-sa-' 'DEUS-na-za |CAPUT-tá$z a-b a ! * 366-n a-n a !$ (DEUS) TONITRUS-tá-ti-

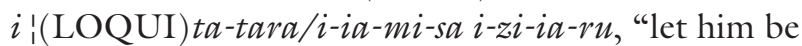
made accursed by Tarhunzas in the sight of(?) God and men!" ${ }^{30}$ Additionally, during the last Phrygian Conference, I adduced a Greek text contemporary to the NPhr. one, ${ }^{31}$ an inscription found in a house at Seferihisar (Sevri Hissar), near ancient Teos (Ionia):

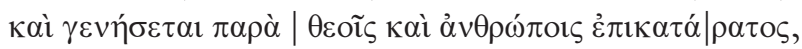
"and let him become accursed in the sight of gods and men": (Strubbe, no. 32). This curse confirms the unclear meaning of the Luwian *366-na-na and Phrygian $\mu \varepsilon$ through its equivalent position to Greek $\pi \alpha \rho \alpha ́$ + dative.

Finally, the last occurrence of Bas appears in NPhr. 48 , in a short list of three divine names mentioned in

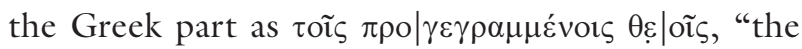
inscribed gods":

the author for kindly sending me a draft of this paper prior to its publication.

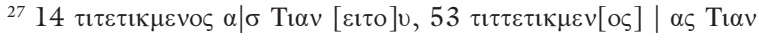

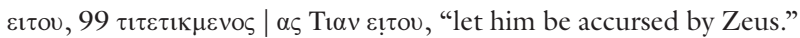

${ }^{28}$ Lubotsky, "Phrygian Zeus": 127-28.

${ }^{29}$ Th. Drew-Bear, A. Lubotsky, and M. Üyümez, "Three New Phrygian Inscriptions," Kadmos 47 (2008): 115-16.

${ }^{30}$ Bauer, Morphosyntax of the Noun Phrase, 131.

${ }^{31}$ Obrador-Cursach, "Luwian origin of the Phrygian imprecations." 
Table 1 - Inflection of Bat- in comparison with nevos

\begin{tabular}{|c|c|c|c|}
\hline Case & Bas & nevos & PIE endings \\
\hline Nom. Sg. & $\mathrm{B} \alpha \mathrm{s}$ & nevos & ${ }^{*}-t-s$ \\
\hline Acc. Sg. & Batan / B $\alpha \tau \alpha \nu$ & nevotan & ${ }^{*}-t-m$ \\
\hline
\end{tabular}

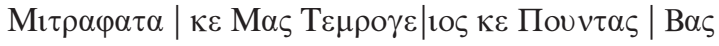
$\kappa \varepsilon \varepsilon v \sigma \tau \alpha \rho v \alpha$

Here, Bas appears in the nominative and is quali-

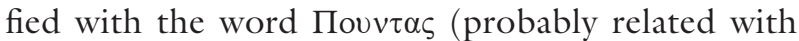
the Pontic region, a genitive of this toponym?). Ac-

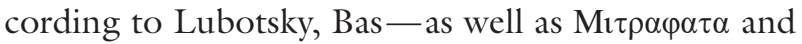

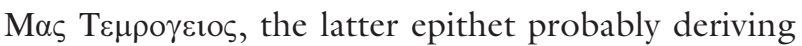
from the region of the Tymbris - is the subject of the verb $\varepsilon v \sigma \tau \alpha \rho v \alpha$, which traces back to the PIE root *steh_-, "stand, make stand" (LIV² 590-92; see, e.g.,

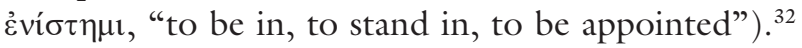
Consequently, partially applying Lubotsky's interpretation, the approximate meaning of this sentence is: "Mitrafata and the Tem(b)rogic Mas and the Pontic Bas were appointed."

In all inscriptions, only two forms of the theonym Bas are documented: the nominative Bas $(48,86,99$, and 111) and the accusative Batan (almost in T-02b) / $\operatorname{B} \alpha \tau \alpha v(21,33,36)$. Despite the scarce number of preserved cases, its accusative shows that this is a $t$-stem noun. Indeed, its ending - $t$-an must go back to * $-t-m$, with the preservation of the final nasal sound and the change ${ }^{*}-m>-n$. A suitable parallel is the recently identified word nevotan $(\mathrm{B}-04)<\mathrm{PIE}$ * népotm, the accusative form of the nominative nevos $(\mathrm{B}-05)<\mathrm{PIE}$ * népotts. ${ }^{33}$ Moreover, this nominative also shows the shift * $-t-s>-s$, so Bas must be understood as a simplification of *bat-s (see Table 1).

Therefore, the inflection of this theonym has been identified, but its etymology is uncertain. Until now, only three possibilities have been suggested. First, Haas $^{34}$ argued the similarity between Bas and the PIE root $b^{b} e h_{2}^{-}$, "speak" (LIV² 69-70), e.g., Greek $\varphi \eta \mu i$, pávar, “id.” or Latin for / fari, “id.”. Nevertheless, Haas compared B $\alpha \varsigma$ with the Greek $\gamma \tilde{\eta}$, "earth." As indicated, this comparison is not supported by our accepted knowledge of Phrygian. On the other hand, I. M. Diakonoff and V. P. Neroznak adopted Haas'

\footnotetext{
${ }^{32}$ Lubotsky, "New Phrygian Inscription No. 48," 123-24.

${ }^{33}$ A. E. Hämmig, "Nevotan niptiyan. Die Fluchformel der Stele von Vezirhan," Indogermanische Forschungen 118 (2013): 134-38.

${ }^{34}$ Haas, Die phrygischen Sprachdenkmaler, 97.
}

interpretation, ${ }^{35}$ and even Brixhe has considered this possibility, although he was not entirely convinced by this interpretation, and ultimately abandoned it. ${ }^{36} \mathrm{~K}$. Witczak introduced into the discussion two obscure Mycenaean terms: $p a-d e-i$ and $p a-d e .{ }^{37} \mathrm{He}$ read them as ${ }^{*} \Phi \alpha \varsigma, \Phi \alpha \delta \circ \varsigma$, and equated them to Old Polish Boda and dubiously with Old Indian Bhadrā. The result of his comparison reverted the translation to the reconstructed root * $b^{b} a d$-, "fortunate, happy, prosperous; good" (IEW 106), and attributed a Bithynian origin of this theonym in order to avoid the phonetic problems of his etymological proposal. However, Lubotsky dismissed Witczak's argumentation as ungrounded. ${ }^{38}$

With these inconclusive interpretations, and having verified that the word Bas does not exist in surrounding languages, only determining the internal reconstruction remains in order to identify the origin of this theonym. Thus, I propose that the theonym Bas is a Phrygian derivative $t$-stem from the PIE root ${ }^{*} b^{b} e h_{2}$, "shine" (LIV² 68-69). ${ }^{39}$ According to its inflection, it can be a primary $t$-stem formation, but it only fits

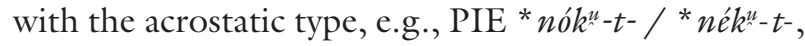
"night." Therefore, the form * $b^{b} o_{2}-t-/{ }^{*} b^{b} e^{\prime}-t$ - can be assumed as the origin of this theonym. However, the nom. Bas presents a problem. If the laryngeals in Phrygian work in the same way as they seem to in Greek, a nominative ${ }^{*} \beta \omega \varsigma$ and accusative ${ }^{*} \beta \omega \tau \alpha \nu$ would be predictable. Nevertheless, the nominative and accusative root vowel may have been levelled from oblique cases, where $e$-grade is expected. Unfortunately, they are not attested. However, this is not the only levelling assumed in Phrygian, since A. Kloekhorst recently argued such a levelling for the word

${ }^{35}$ I. M. Diakonoff and V. P. Neroznak, Phrygian (Delmar, NY, 1985), 97.

${ }^{36}$ Brixhe, "Les inscriptions paléo-phrygiennes de Tyane," 42. See also C. Brixhe, "Du paléo- au néo-phrygien," Académie des Inscriptions \& Belles-Lettres. Comptes rendus des séances de l'année 137/2 (1993): 331, and "Les clitiques du néo-phrygien," in Frigi e Frigio. Atti del $1^{\circ}$ Simposio Internazionale. Roma, 16-17 ottobre 1995, ed. R. Gusmani, M. Salvini and P. Vannicelli (Roma, 1997), 51 .

${ }^{37}$ K. Witczak, "Two Bithynian Deities in the Old and New Phrygian Inscriptional Text," Folia Orientalia 29 (1992-1993): 67-68.

${ }^{38}$ Lubotsky, "New Phrygian Inscription No. 48," 123 n. 12.

${ }^{39}$ Note that very often ${ }^{*} b^{b} e_{2}-$, "speak" (LIV ${ }^{2}$ 69-70), is considered to be the same root with a semantic development: see G. E. Dunkel, "Latin iubar and fās," in Sound law and analogy: papers in honor of Robert S. P. Beekes on the occasion of his 60th birthday, ed. A. Lubotsky, (Amsterdam, 1997), 31. However, this issue does not pertain to the proposal of this paper. 
petes, "feet" (pl.nom.) ${ }^{40}$ where the expected $o$-grade of the PIE root has been substituted for the $e$-grade of the oblique cases (neither attested). Additionally, these morphological considerations fit the context. These formations are considered verbal abstracts in origin, which often become concrete nouns, e.g., PIE *doh ${ }_{3} t$-, "giving" > Latin dōs, -ottis, "dowry." Therefore, the development from "shining" into "the shine" and later "the shining one" can be considered, forming a suitable name for a god.

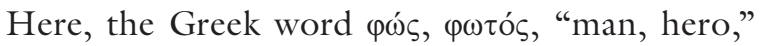
can be adduced to support this new interpretation. K. Brugmann and B. Delbrück ${ }^{41}$ equated this word with the Vedic s-stem bhás-, "light, splendor, power," and assumed that the Greek word was indeed a secondary $t$-stem noun, as well as many others in this language. After a century during which this explanation remained more or less unaccepted, ${ }^{42} \mathrm{M}$. Peters improved the formal analysis of this etymology and opened the possibility of an ancient $t$-stem agentnoun without excluding an original radical noun. ${ }^{43}$ On its meaning, he considered that the word developed from "shining," adducing some Indo-European formulae which associate this concept with heroes (consequently, the meaning "man" is a secondary one). He also considered the Greek personal names in $-\varphi \omega \varsigma,-\varphi \circ \varsigma \varsigma$, and $-\varphi \omega \sigma \sigma \alpha$, equivalent to Old Persian -farnah- and Avestan -xvaranah-, in order to show this association. More recently, A. Vijūnas has argued that this Greek word originated from a primary $t$ stem,${ }^{44}$ the same kind of formation suggested here for the Phrygian word (see also NIL 7-11) ${ }^{45}$ where the whole Greek paradigm has levelled the 0 -grade of the root from the nominative and accusative singular (the opposite way of the Phrygian word, see Table 2).

${ }^{40}$ A. Kloekhorst, "The Old Phrygian word for 'feet': new readings in the 'podas'-inscription (G-02)," Kadmos 54.1 (2016): 115.

${ }^{41} \mathrm{~K}$. Brugmann and B. Delbrück, Grundriss Vergleichenden Grammatik der Indogermanischen Sprachen 2.1 (Berlin, 18971916): 536.

${ }^{42}$ Pierre Chantraine, Dictionnaire étymologique de la langue grecque: histoire des mots (Paris, 1968-1980), 1238.

${ }^{43}$ M. Peters, "Beiträge zur Griechischen Etymologie," in Miscellanea Linguistica Graeco-Latina, ed. L. Isebaert (Namur, 1993), 101-108; see also Dunkel, "Latin iubar and fās," 32.

${ }^{44} \mathrm{~A}$. Vijūnas, The Indo-European primary t-stems (Innsbruck, 2009), 72-76.

${ }^{45}$ D. Wodtko, B. Irslinger and C. Schneider, Nomina im Indogermanischen Lexikon (Heidelberg, 2008) (abbreviated here NIL).
Table 2-Proposed development of PIE *bhóh2-t- in Phrygian and Greek

\begin{tabular}{|c|c|c|c|}
\hline Case & PIE & Phrygian & Greek \\
\hline Nom. Sg. & ${ }^{*} b^{b} o h_{2}-t-s$ & $\mathrm{~B} a \varsigma$ & $\varphi \omega ́ \varsigma$ \\
\hline Acc. Sg. & ${ }^{*} b^{b} o^{2} h_{2}-t-m$ & Batan / B $\alpha \tau \alpha v$ & $\varphi \tilde{\omega} \tau \alpha$ \\
\hline Gn. Sg. & ${ }^{*} b^{b} e ́ h_{2}-t-s$ & - & $\varphi \omega \tau o ́ \varsigma$ \\
\hline
\end{tabular}

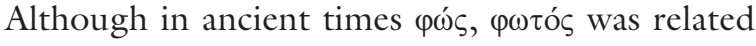
to "light" (as Apollonius the Sophist showed), ${ }^{46}$ this etymology is not commonly accepted. Some scholars refute it because they consider it "semantically implausible." ${ }^{47}$ Indeed, no satisfactory explanation of this suggested semantic development has been proposed and, what is worse, it seems that there is no synchronic evidence which points out the semantic shift "light" > "hero" > "man." Therefore, in order to accept the suggested etymology, the meaning of the development of $\varphi \omega ́ s, \varphi \omega \tau$ tó from the proposed prehistoric meaning "the shining one" to "hero, man" must be explained.

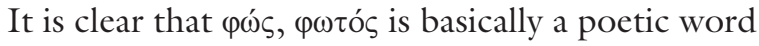
rarely occurring in prose. It means that the use of this noun was restricted to the elevated style of epic or tragedy, far from common language usage. Certainly, the two usual meanings, "hero" and "man," are inferred from the context. $\Phi \omega ́ \varsigma$ means "hero" when it is used to qualify some characters such as Achilles (Iliad 2.239 ), although in other occurrences it clearly con-

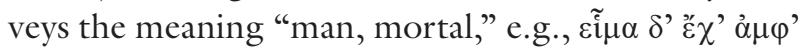

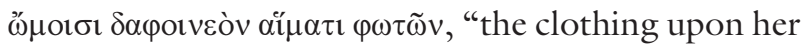
shoulders showed strong red with the men's blood" (Iliad 18.538).

Sometimes this noun appears in apposition to personal names, similar to epithets, especially in two for-

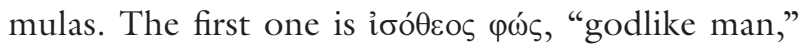
said of Euryalus (Iliad 2.565 and 23.677), Priam (Iliad 3.310), Menelaus (Iliad 4.212 and 23.569), Ereuthalion (Iliad 7.136), Patroklos (Iliad 9.211 and 11.644), Sokos (Iliad 11.428), Aias (Iliad 11.472 and 15.559), Meriones (Iliad 16.632), Odysseus (Odyssey 1.324), and Telemachus (Odyssey 20.124). The second

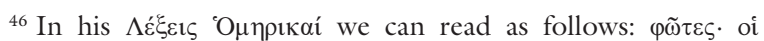

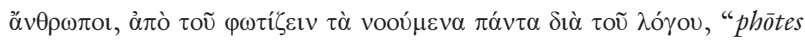
[refers to] humans because they illuminate all thoughts through the reason." However, this association might be given because of the

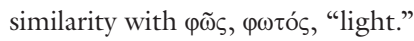

${ }^{47}$ R. S. P. Beekes, Etymological Dictionary of Greek (Leiden, 2010), 1602, similar to the expression used by Chantraine, "Dictionnaire étymologique," 1238. 
formula is the patronymic scheme $\varphi \tilde{\omega} \tau \tau^{\prime}$ [name in genitive] viòv, where $\varphi \tilde{\omega} \theta^{\prime}$ is always found in the beginning

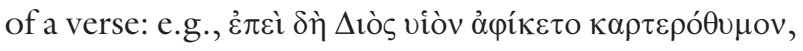

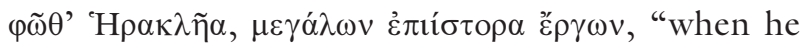
came to Zeus's son, the mighty-hearted man Heracles, a master of monstrous deeds" (Odyssey 21.25-26); or

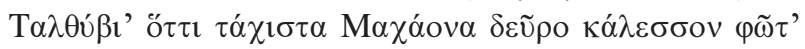

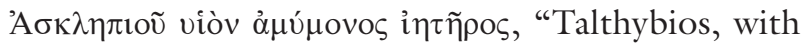
all speed go call hither Machaon, a man who is son of Asklepios and a blameless physician" (Iliad 4.193-94).

Finally, in some contexts $\varphi \omega ́ s$ is clearly opposed

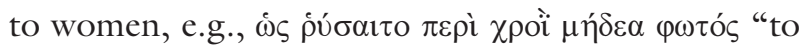
pull over his body to cover his man's genitals" (Odyssey 6.129 ), although in a few instances (although never in Homer) it refers to a couple of man and woman,

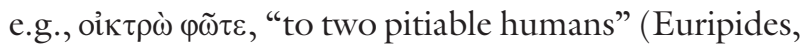
Helen 1094, in dual, referring to Helen and Menelaus).

In light of this last context, it is clear that the word was not comprehensible to the audience of the Homeric poems. Moreover, it can be deduced that the original meaning is not the generic "human," because it is never said of a woman, so it likely means "man." However, in many contexts it is used to refer to warriors and, especially in singular, to the important ones. Thus it can be concluded that this word, despite its poetic value, is a semantically empty archaism.

Before explaining the consequences of such a conclusion, a similar case can be adduced. There is another archaism understood as "men" despite the lack of a clear etymology: $\mu \varepsilon \varepsilon^{\circ} \pi \varepsilon \varsigma$. Although its original meaning is unknown, ${ }^{48}$ in Homer it is always used in the plural as an epithet of o $\alpha \theta \rho \omega \pi \mathrm{or}$, "men" (e.g., Iliad 18.288) and, sometimes, of ßpotoí, "mortal men" (Iliad 2.285). In other texts, it is attested with $\lambda \alpha o$, "men, people" (Aeschylus, Suppliant Women 90). In such cases, it was understood as "mortal." However, in the works of tragic authors and later poets, the word occurs as a noun with the meaning "men." Finally, it is reported to be the name of a bird (Aristoteles, History of Animals 615b.25). Leaving aside this bird name, it is evident that $\mu \varepsilon \varepsilon_{\rho} \pi \varepsilon \varsigma$ did not have a clear meaning for ancient Greek speakers, and the meaning "men" is only inferred from its relation with ơ $v \theta \rho \omega \pi \mathrm{or}$ in Homer.

The same could then be said of $\varphi \omega ́ s:$ its original meaning was unclear, but it was understood as "men" or "hero" because it appeared in relation to them. Indeed,

${ }^{48}$ Beekes, Etymological Dictionary of Greek, 933. what happened here is a well-established phenomenon called "productive misunderstanding" by M. Leumann, “iconism” by M. S. Silk (from a literary perspective) and, equating it to modern languages, "irrational resemantization" or "irrational polysemy" by Méndez Dosuna. ${ }^{49}$ Certainly it has been claimed for archaic words in Homer which later speakers misunderstood, but, because of the importance of their literary tradition, were still used with a new meaning deduced from context. It is the case for many adjectives and (especially) epithets, since they play a peripheral role in sentences.

A good example of this process is found in the adjective a'ónos, which combines the meaning "quick, nimble, shimmering" with "variegated, colorful," two meanings not conceivable with a natural semantic shift. According to Méndez Dosuna, it originally meant "variegated, colorful" 50 and, as a later invention of the glossographoi, it was understood also as "quick." Another paradigmatic example of such a misunderstanding is $\kappa u ́ \mu \beta \alpha \chi \circ \varsigma$, earlier used as a technical noun ("crest of a helmet"), and later as an adjective ("falling head-first"). ${ }^{51}$

Nevertheless, there is a significant difference between $\varphi \omega ́ \varsigma$ and $\mu \varepsilon \dot{\varepsilon}$ олєє. Indeed, while the latter is far

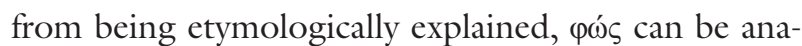
lyzed as an inherited PIE word with a primary meaning: "shining, radiance." Thus, its unnatural semantic shift is a parallel process to the meanings of aiónos.

As it has been said, it seems that there is no synchronic evidence in Greek for the meaning "shining, radiance." That is why $M$. Peters needed to adduce the Old Irish collation luan láith, "hero's light" as a semantic parallel of his proposal. ${ }^{52}$ Nevertheless, this

${ }^{49}$ M. Leumann, Homerische Wörter (Basel, 1950), 231-33; M. S. Silk, "LSJ and the problem of poetic archaism: from meanings to iconyms," Classical Quarterly 33 (1983): 303-30; J. Méndez Dosuna, "La polisemia del gr. ảpyós ('blanco', 'veloz')," Nova Tellus 30/2 (2012): 11-37, and "Glosografía griega y polisemia irracional: la verdadera historia de aióios" in Ianua Classicorum: temas y formas del mundo clásicos. Actas del XIII Congreso Español de Estudios Clásicos (Logroño, 18-23 de julio de 2011), ed. J. de la Villa Polo et al. (Madrid, 2015), 357-94.

${ }^{50}$ Méndez Dosuna, "Glosografía griega y polisemia irracional." He refutes that synesthesia worked here by analyzing the Greek data and the parallels in other languages.

${ }^{51}$ Leumann, Homerische Wörter, 231-33; Silk, "LSJ and the problem of poetic archaism," 305-306; Beekes, Etymological Dictionary of Greek, 801.

${ }^{52}$ Peters, "Beiträge zur Griechischen Etymologie," 105. 
parallel is unclear ${ }^{53}$ and unnecessary. Indeed, the image of a hero imbued with a shining appearance is explicitly depicted in some passages of the Iliad. See, e.g., Iliad 5.4-6, where Diomedes' helmet shines due to the intervention of Athene:

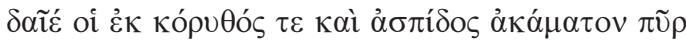

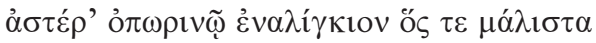

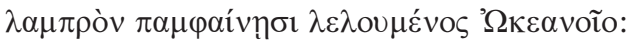

[Athena] made weariless fire blaze from his shield and helmet, like that star of the waning summer who beyond all stars rises bathed in the ocean stream to glitter in brilliance. ${ }^{54}$

A similar scene is found related to Achilles in Iliad 18.205-14:

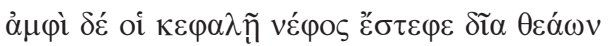

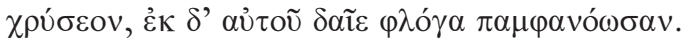

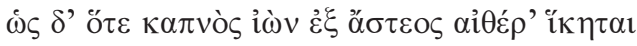

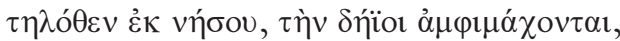

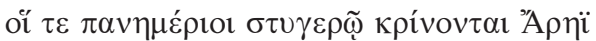

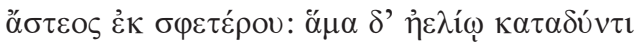

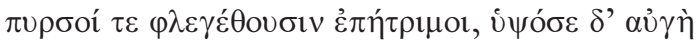

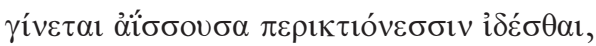

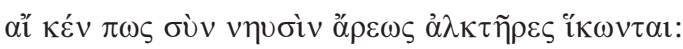

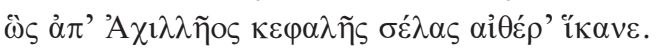

... and [Athena], the divine among goddesses, about his head circled a golden cloud, and kindled from it a flame far-shining. As when a flare goes up into the high air from a city from an island far away, with enemies fighting about it who all day long are in the hateful division of Ares fighting from their own city, but as the sun goes down signal fires blaze out one after another, so that the glare goes pulsing high for men of the neighbouring islands to see it, in case they might come over in ships to beat off the enemy; so from the head of Achilleus the blaze shot into the bright air.

Consequently, the "shining warrior" can be considered a Homeric motif which provides a context

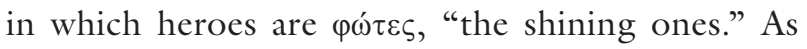

\footnotetext{
${ }^{53}$ On this Old Irish collation see Brend, Heroic saga and classical epic in Medieval Ireland (Cambridge, 2011), 222-23. Leaving aside the textual problems related to lúan láith, it could be lately influenced by Classical literature.

${ }^{54}$ Translation of Iliad and Odyssey passages are given according to The Chicago Homer (Lattimore's and Huddleston's, respectively): http://homer.library.northwestern.edu/.
}

is shown in these two instances, the divinity (here Athena) gives to the warriors an attribute which is considered divine: brightness. Certainly, the Greek gods are known to be imbued with a brilliant aura when they appear in their true form. ${ }^{55}$ A good description of this feature is found in the Homeric Hymns. See, e.g., how Demeter is depicted at Keleos' house (Hymn to Demeter, 187-88 and 277-80):

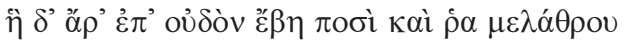

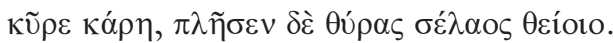

$$
[\ldots]
$$

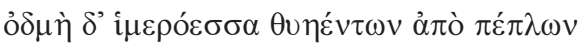

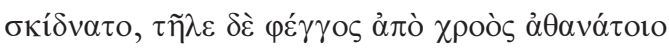

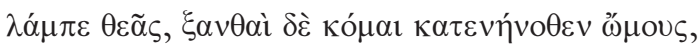

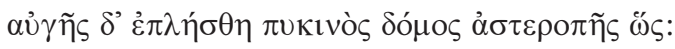

But the goddess walked to the threshold: and her head reached the roof and she filled the doorway with a heavenly radiance. [. . . ] Beauty spread round about her and a lovely fragrance was wafted from her sweet-smelling robes, and from the divine body of the goddess a light shone afar, while golden tresses spread down over her shoulders, so that the strong house was filled with brightness as with lightning.

Also Apollo is described in a similar way when he enters into his temple in Delphos for the first time (Hymn to Apollo 440-45):

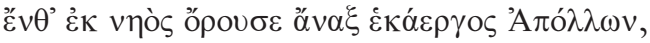

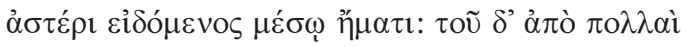

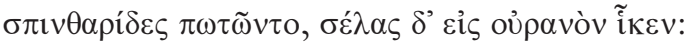

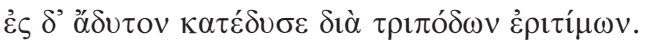

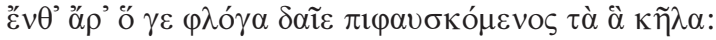

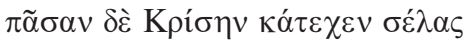

Then, like a star at noonday, the lord, far-working Apollo, leaped from the ship: flashes of fire flew from him thick and their brightness reached to heaven. He entered into his shrine between priceless tripods, and there made a flame to flare up bright, showing forth the splendor of his shafts, so that their radiance filled all Crisa.

${ }^{55}$ See M. L. West, The East Face of Helicon: West Asiatic Elements in Greek Poetry and Myth (Oxford, 2003), 113-16. West compares it to other gods from the ancient Near East. The examples from the Homeric Hymns adduced here are taken from this book. However, the following translations are given according to Hugh G. Evelyn-White. 
In consideration of these passages, the formula

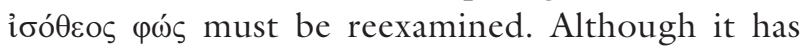
been interpreted as "godlike man," it very likely means "the godlike shining one, he who shines like gods." A complement to this occurrence is Menelaus' speech in Iliad 17.96-105, in which he is afraid of attacking Hector, considered a superior warrior:

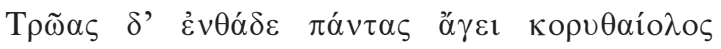
${ }^{e} \mathrm{E} \kappa \tau \omega \rho$.

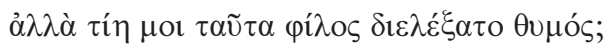

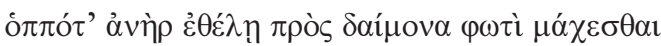

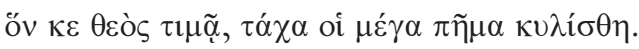

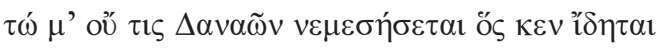

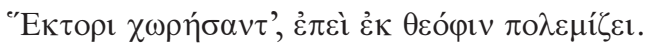

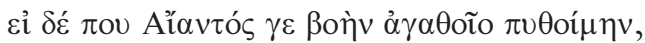

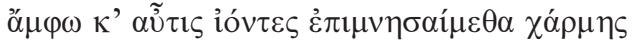

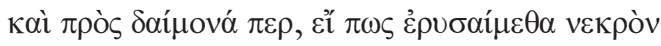

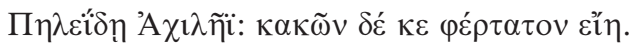

Hektor of the shining helm leads all of the Trojans here. Then why does my own heart within me debate this? When a man, in the face of divinity, would fight with another whom some god honours, the big disaster rolls sudden upon him. Therefore, let no Danaan seeing it hold it against me if I give way before Hektor, who fights from God. Yet if somewhere I could only get some word of Aias of the great war cry, we two might somehow go, and keep our spirit of battle even in the face of divinity, if we might win the body for Peleïd Achilleus. It would be our best among evils.

In this soliloquy, Menelaus is afraid of fighting with Hector because the Trojan hero fights with divine aid.

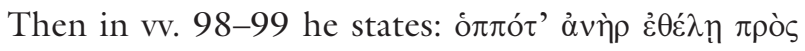

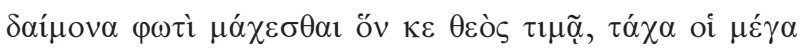
$\pi \tilde{\eta} \mu \alpha \kappa \nu \lambda i \sigma \theta \eta$, "When a man [= $\dot{\alpha} v \eta े \rho]$, in the face of divinity, would fight with another man $[=\varphi \omega \tau i]$ whom some god honours, the big disaster rolls sudden upon him." Note that here Hector is clearly equated to this $\varphi \omega ́ s$, who is honored by a god, and Menelaus to the plain àvì $\rho$, who cannot beat his great adversary.

In conclusion, what happened to $\varphi \omega ́ s$ is that at one moment the use of this word was restricted to epic verses and later misinterpreted by Greek speakers. Nevertheless, because of its literary significance, $\varphi \omega ́ s$ was reused with its apparent sense "hero, man." According to this consideration, the etymology $\varphi \omega ́ \varsigma<$ * $b^{b} o h_{2}-t-s$, "shining," is a valid one.
Leaving aside the Greek word, the interpretation suggested for the Phrygian theonym provides a suitable scenario which aligns with an Anatolian divinity. Indeed, common epithets of the Storm-God in Hittite texts are the adjectives pibaim $(m) i-$, pibam $(m) i-$, and pibassassi-, derived from a Luwian word piba- (attested in the Hieroglyphic Luwian inscription Karatepe I $\$ 52) .{ }^{56}$ According to CHD s.v. pibaim $(m) i-,{ }^{57}$ since sometimes these adjectives are placed in juxtaposition, their meaning must be different; but this distinction cannot be substantiated because all forms share origin and context. CHD then compares their meaning with the difference between English "joyful” and "joyous," and interprets these epithets as "imbued with splendor/might." Therefore, Phrygian Bas is very likely a calque of the Luwian epithets used to qualify Tarhunt.

At this point, it must be said that S. Bernd-Ersöz suggested that evidence existed for a Storm-God in Phrygian monuments ${ }^{58}$ and that this god was called

${ }^{56}$ F. Starke, Untersuchungen ur Stammbildung des kelischriftluwischen Nomens (Wiesbaden, 1990), 103-106, suggested that piba- was a derivative from the PIE root ${ }^{*} b^{h} e h_{2}^{-}$, "shine" (LIV ${ }^{2}$ 68-69), a vrddhi formation where Eichner's Law worked: * $b^{b} \overline{{ }^{2}} h_{2}^{-0-}$. Although some people still operate with this etymology (see, e.g., H. C. Melchert, "Naming Practices in Second- and First-Millennium Western Anatolia," in Personal Names in Ancient Anatolia, ed. R. Parker [Oxford, 2013], 34, or D. Schürr, "Zur Herkunft des Pegasos," Graecolatina et Orientalia 35-36 [2014]: 114-16), Eichner's Law is discussed and, consequently, Starke's proposal is not accepted by all scholars. Thus, A. Kloekhorst, Etymological Dictionary of the Hittite Inherited Lexicon (Leiden, 2008), 674-76, claimed that a new etymology is to be found in other PIE verbal roots, and that the meaning of Luwian piba- must be established in the light of Phoenician $\{z$, "power, strength," the equivalent of "FULGUR"- há-sá / pihas=sa/ in the Phoenician version of the bilingual inscription Karatepe 1 . However, this is not so easy, since the Luwian rendering of this inscriptions shows many inaccuracies (see I. Yakubovich, "Phoenician and Luwian in Early Iron Age Cilicia," Anatolian Studies 65 [2015]: 46-48), and the expected equivalent for Phoenician $\lceil z$, "might" is muwatta- (Melchert, pers. Comm., February 24, 2016). Recently, I. Yakubovich ("The degree of comparison in Luwian," Indogermanische Forschungen 119 [2015]: 157 n. 5) considered that the cultural term piba-, "predetermined with FULGUR 'lightning', is akin in its meaning to the Akkadian melammu-, the mystic aura of gods, heroes, and kings." This Akkadian concept is also equated to the brightness of the Greek gods by West, East Face of Helicon, 113-16.

${ }^{57}$ H. G. Güterbock and H. A. Hoffner, The Hittite Dictionary of the Oriental Institute of the University of Chicago (Chicago, 1997), 253 (abbreviated here CHD).

${ }^{58}$ S. Bernd-Ersöz, "In Search of a Phrygian Male Superior God," in Offizielle Religion, lokale Kulte und individuelle Religiosität. Akten des religionschichtlichen Symposiums "Kleinasien und angrezende Gebiete vom Beginn des 2. bis zur Mitte des 1. Jahrtausends v. Chr.” 
Atas. ${ }^{59}$ Her argument starts with the fact that sometimes the so-called Phrygian idol, a schematic human depiction related to the Mother-Goddess, has another adjoining representation. According to her, the second idol could stand for the Phrygian Superior Male god (likely the Anatolian Storm-God) in the light of the mini-relief of the Mother-Goddess from Gordion, where also a bull, icon of the Storm-God, was represented (a common Anatolian iconographic motive). She suggested his name was Atas, arguing that, in Hittite, atta-, "father," is sometimes used "for the Father of the gods or Father god," and she considered that the Phrygian Atas meant "father," too. Nevertheless, no occurrence of the Phrygian Atas happens in a context where a god is expected, and it is well attested as an anthroponym both in Phrygian and Greek inscriptions from Phrygia. Atas is the dedicatee of the inscription W-10, ${ }^{60}$ since it occurs in the dative Atai. However, in the Phrygian corpus, many inscriptions are dedicated to men, and even the OPhr. M-0la, engraved on a façade (a kind of monument dedicated to the Mother-Goddess), is dedicated to the king Midas almost two centuries after his death. Moreover, despite the common etymology for this Lallname (the Anatolian word for "father"), in Phrygian it is never used as a common noun, while the inherited IE word $p h_{2} t t^{\prime} r$ $/ p h_{2} t r-$,' "father" (NIL 554-562), is twice attested in nominative plural ( $\pi \alpha \tau \varepsilon \rho \eta \varsigma 48$ and its syncopated variant $\pi \alpha \tau \rho \varepsilon \varsigma 130$ ) denoting "parents." Consequently, perhaps for Phrygian speakers, it was a meaningless personal name as other Lallnamen, like Baba (M-01b and G-121) or Tatas (G-04). Despite these considerations, her identification between a Phrygian Storm-

(Bonn, 20.-22. Februar 2003), ed. M. Hutter and S. Hutter-Braunsar (Münster, 2004), and S. Bernd-Ersöz, Phrygian Rock-Cut Shrines: Structure, Function, and Cult Practice (Leiden, 2006), 161-66.

${ }^{59}$ Since the Phrygian alphabet does not mark geminate consonants and Greek occurrences of this personal name are written as A $\tau \tau \alpha \varsigma$ (including two Hellenistic inscriptions from Gordion, L. E. Roller, "Hellenistic Eipgraphic Text from Gordion," Anatolian Studies 37 [1987]: nos. 48 and 50; see also L. Zgusta, Kleinasiatische Personennamen [Prag, 1964; abbreviated here KPN], 106-107 \$ 119-9), Ata and Atai must stand for /Attas/ and /Attai/. In OPhr. texts, the nominative does not take any ending: Ata is clearly read in G-107, G-118, G-224a, G-234, and HP-111. On the other hand, there is a variant of this personal name: Ates $\mathrm{M}$ 01a, W-08, G-123, HP-103, HP-104, HP-105, HP-106, HP-107,

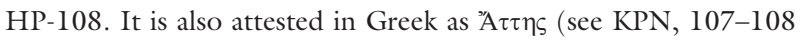
\$ 119-10).

${ }^{60}$ Still a very obscure text incised on the wall of a rock: Atai edae

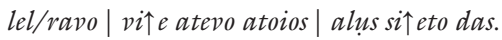

God and some representations remain valid, ${ }^{61}$ and only the name given to this deity must be changed.

As a concluding remark, the relation between $\mathrm{B} \alpha \varsigma$ and $\mathrm{Tt}^{-}$, the Phrygian Zeus, ${ }^{62}$ must be explained. Indeed, it is known that the Anatolian Storm-God was

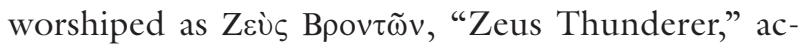
cording to Greek inscriptions from Roman Phrygia. ${ }^{63}$ It means that Tarhunt was assimilated to Zev́s. But what is the place of Bas here? The most economical explanation is to consider that the syncretism between the Anatolian Storm-God Tarhunt and Zzús, his Greek counterpart, also happened between Tarhunt and Ti-, the Phrygian Zeus, in the beginning of the first millennium BC. Therefore, B $\alpha$ and $\mathrm{Tt}_{\mathrm{t}}$ - can be considered two epikleseis of the Phrygian Superior Male god. This elucidation explains two features related to Bas and $\mathrm{Tt}$ - in the Phrygian curses.

The first one is the presence of Bas in the imprecative apodosis of NPhr. 128: $\mu \varepsilon \delta \delta \varepsilon \omega \mu \varepsilon \zeta \varepsilon \mu \varepsilon \mid \lambda \circ \varsigma$

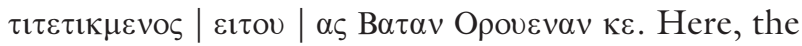
expected god is $\mathrm{Tt}^{-}$- (Tarhunt in the Luwian equiva-

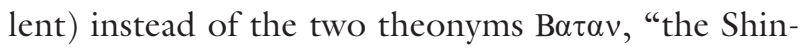
ing one," and Opovevav, "the Keeper." So these two designations can be considered two epithets denoting

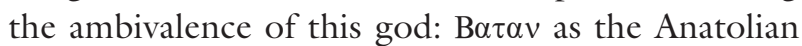
Storm-God and Opovevav as the inherited Phrygian Zeus, worshiped in a similar way to Greek Zev́s $\pi \alpha \tau \eta े \rho$ or Latin Iuppiter. Moreover, the presence of two contiguous epikleseis of the same god is common in Anatolia from Hittite times to the Roman Imperial

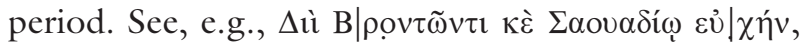
"vow for Zeus the Thunderer and the Sabadios" (SEG 8.1307,A, from Avdan, near Dorylaion), or $\Delta \mathrm{ù}$

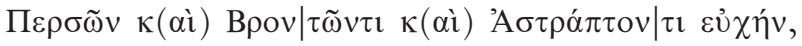

${ }^{61}$ I.e., the double idols and the bull from Gordion. Also, the strong possibility that the statue found in Kerkenes Dağ represents the Storm-God must be considered. On this find, see C. M. Draycott and G. D. Summers, Sculpture and Inscriptions from the Monumental Entrance to the Palatial Complex at Kerkenes Dağ Turkey, (Chicago, 2008), 10-21, who considered among other possibilities (i.e., a ruler or a goddess) that "it is also possible that the figure represents an elusive Phrygian god." The mace, which this statue bears, can be equated to a common attribute of Tarhunt.

${ }^{62}$ The name of the Phrygian Zeus is attested in the accusative Tıav < ${ }^{*}$ diēm (parallel to Greek Zñv), in the genitive Tios<

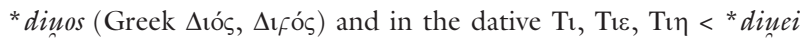
(Greek $\Delta \mathbf{t i ́}^{\prime} \Delta \mathrm{t} f \mathbf{i}$ ), its etymology and inflection where identified by Lubotsky, "Phrygian Zeus," 230.

${ }^{63}$ On its cult, see Th. Drew-Bear and C. Naour, "Divinités de Phrygia," ANRW II 18.3 (1990): 1992-2013. 
"vow for Zeus of the Persians and the Thunderer and the Lightner" (from Nacoleia). ${ }^{64}$

The second feature explained by this interpretation is the relation between the god Bas and $\beta \varepsilon \kappa о \varsigma$, "bread." Indeed, the association of the Storm-God with crops and food is a common topos in the ancient Near East. It is explicit, e.g., in the Hittite myth of the missing Storm-God (CTH 325): [ ${ }^{\mathrm{d} I M-a s ~ a t t] ~} a s^{r}$ DINGIR ${ }^{\text {MEšs }}-a \grave{s} \operatorname{tars}(i) k k e z z i \mid$ DUMU- $\Upsilon A=w a=k a n$ [andan NU.GÁL] | [s] $\bar{a} e t=w a r=a n=z a \mid n u=w a=z$ büman ā [šsu pédaś] | [balk] in 'immarnin šalhanti[ $n$ manni]ttin išpiyatarr=a peddaš, "[The Storm God's father] said: 'My son [is not there]. He became angry and [carried off] everything good. He carried off grain, animal fecundity, abundance, plenty, and satiation.". ${ }^{65}$ It is even found in a similar apodosis to the Phrygian ones, in the inscription from Sam'al devoted to Hadad by Panamuwa I (first half of the eighth century BC): ${ }_{2} ?_{1} l \cdot y t n \cdot l h \cdot l 2 k l \cdot b[r]_{\llcorner} g_{1} z$, "and may [Hadad] not give to him to eat because of his rage." This relation, explained by the vital importance of rainwater for irrigation purposes, is also found in the Greek inscriptions from Phrygia, where Zeus is invoked, e.g., as

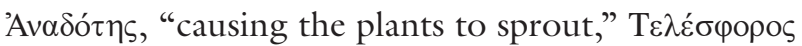

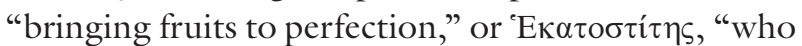

${ }^{64}$ Th. Drew-Bear, Nouvelles inscriptions de Phrygie (Zutphen, 1978), 48 no. 25 = SEG 28.1186.

${ }^{65}$ Translated by H. A. Hoffner, Hittite Myths (Atlanta, 1998), 21. makes crops bear a hundredfold." ${ }^{66}$ It is even more explicit in the following hexametric prayer to Zeus from Dorylaion (AD 175):

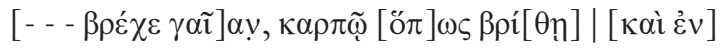

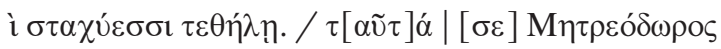

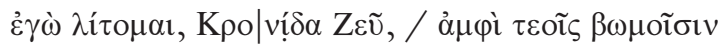

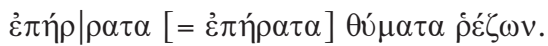

[Zeus ... wet the ea]rth, that she become heavy with fruit and flower with ears of corn. This I, Metreodoros, beg of you, Zeus son of Kronos, as I perform delightful sacrifice on your altars. ${ }^{67}$

In conclusion, considering the parallels of the Phrygian imprecations adduced here, where Bas occupies the same position of the Luwian Tarhunt or the Aramaic Hadad, the first occurrence of this god in the Luwian city of Tyana and the suggested etymology, shows that the god Bas fits very well as the Phrygian Storm-God, and that his name can be easily interpreted as a calque of Luwian epithets for this deity.

${ }^{66} \mathrm{I}$ borrow this example form the useful compilation of the cults in Phrygia Epiktetos in the Roman Imperial period presented by M. Ricl during the last Phrygian Conference ("Cults of Phrygian Epiktetos in the Roman Imperial Period," forthcoming in Tsetskhladze, ed., Phrygian Lands Over Time). I would to thank her kindness in sending me a draft of this paper prior to its publication.

${ }^{67}$ A. Körte, "Kleinasiatische Studien VI", $M D A I(A) 25$ (1900): 421 no. 33; translated by M. Depew, "Reading Greek Prayers," Classical Antiquity 16/2 (1997): 245. 